\title{
Norepinephrine exerts an inotropic effect at the early phase of human septic shock
}

\author{
O Hamzaoui ${ }^{1 *}$, M Jozwiak ${ }^{2}$, T Geffriaud ${ }^{2}$, B Sztrymf ${ }^{1}$, D Prat ${ }^{1}$, F Jacobs ${ }^{1}$, X Monnet ${ }^{2}$, P Trouiller ${ }^{1}$, C Richard ${ }^{2}$, JL Teboul ${ }^{2}$ \\ From ESICM LIVES 2015 \\ Berlin, Germany. 3-7 October 2015
}

\begin{abstract}
Introduction
Norepinephrine (NE) is recognized as a potent vasopressor used in septic shock to reverse hypotension. Whether NE still exerts a positive effect on cardiac contractility through beta-adrenergic stimulation is unclear since the sensitivity of beta-adrenergic receptors can be abnormally reduced in septic conditions. Our study was designed to address this issue at the early phase of septic shock.
\end{abstract}

\section{Methods}

We prospectively included patients suffering from septic shock, with a mean arterial pressure (MAP) $<65 \mathrm{mmHg}$ despite initial hemodynamic resuscitation. Echocardiographic measurements were performed before (T0) and after either initiating NE or increasing its dosage in order to achieve a target MAP $>65 \mathrm{mmHg}$ (T1). The following variables were collected: left ventricular ejection fraction (LVEF), velocity-time integral (VTI) of the aortic flow, cardiac output (CO), tissue Doppler imaging of tricuspid annular motion $(\mathrm{Sa})$, peak early transmitral flow velocity (E), tissue Doppler imaging of mean systolic $(\mathrm{Sm})$ and mean early diastolic velocity $(\mathrm{Ea})$ of the lateral mitral annulus and the ratio E/Ea.

\section{Results}

we included 28 patients (mean age of $71 \pm 12$ years), their mean SAPS 2 was $59 \pm 22$, the main sites of infection were the lung in 13 patients, the abdomen in 6 patients and the urinary tract in 5 patients. Eighteen patients were mechanically ventilated. The mean interval time between the start of resuscitation and $\mathrm{T} 0$ was of $141 \pm 72 \mathrm{~min}$. At $\mathrm{T} 0$, patients have already received a mean volume of fluids of $1500 \pm 700 \mathrm{~mL}$. At T0, 15 patients did not yet receive $\mathrm{NE}$ while in the other 13 patients, the mean dose of NE

${ }^{1}$ Paris Sud University, Service de Réanimation Polyvalente, Hôpital Antoine Béclère, Clamart, France

Full list of author information is available at the end of the article was $0.55 \pm 0.62 \mu \mathrm{g} / \mathrm{kg} / \mathrm{min}$. At T1, the mean dose of NE was $0.69 \pm 0.62 \mu \mathrm{g} / \mathrm{Kg} / \mathrm{min}$ for the whole population. From T0 to T1, MAP increased significantly from $56 \pm 7$ to $80 \pm$ $7 \mathrm{mmHg}$, diastolic arterial pressures increased from from $44 \pm 6$ to $59 \pm 12 \mathrm{mmHg}$ and lactate decreased from $3.2 \pm$ 2.2 to $2.3 \pm 1.8 \mathrm{mmol} / \mathrm{L}$ ( $\mathrm{p}<0.05)$. From T0 to T1, LVEF increased from $48 \pm 15$ to $55 \pm 14 \%(\mathrm{p}<0.05)$, Sm increased from $10.7 \pm 5$ to $12 \pm 5 \mathrm{~cm} / \mathrm{s}(\mathrm{p}<0.05)$, VTI increased from $18 \pm 6$ to $20 \pm 7 \mathrm{~cm}(\mathrm{p}<0.05)$, CO increased from $5.6 \pm 1.9$ to $6.1 \pm 2.5 \mathrm{l} / \mathrm{min}(\mathrm{p}<0.05)$, $\mathrm{E}$ increased from $82 \pm 28$ to $94 \pm 30 \mathrm{~cm} / \mathrm{s}(\mathrm{p}<0.05), \mathrm{E} / \mathrm{Ea}$ increased from $9.3 \pm 6$ to $10.5 \pm 6(\mathrm{p}=0.05)$ and $\mathrm{Sa}$ increased from $13 \pm 6$ to $15 \pm 7 \mathrm{~cm} / \mathrm{s}(\mathrm{p}<0.05)$. Even in the 10 patients with a LVEF $\leq 40 \%$ at T0, LVEF and VTI significantly increased (from $33 \pm 6$ to $41 \pm 9 \%$ and from $16 \pm 7 \mathrm{~cm}$ to $18 \pm 9 \mathrm{~cm}$, respectively).

\section{Conclusions}

In spite of the increase in arterial blood pressure and thus in left ventricular afterload, NE administration at the early phase of septic shock increased the indices of left ventricular systolic function, even when the left ventricular systolic function is altered. This suggests that NE actually exerted a significant inotropic effect at the early phase of septic shock in addition to the effect on preload.

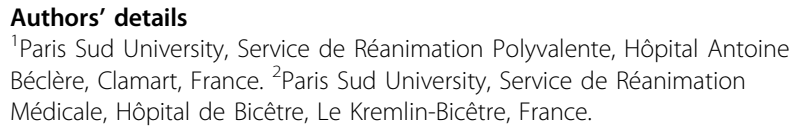

Published: 1 October 2015

doi:10.1186/2197-425X-3-S1-A798

Cite this article as: Hamzaoui et al:: Norepinephrine exerts an inotropic effect at the early phase of human septic shock. Intensive Care Medicine Experimental 2015 3(Suppl 1):A798.
(C) 2015 Hamzaoui et al.; This is an Open Access article distributed under the terms of the Creative Commons Attribution License (http://creativecommons.org/licenses/by/4.0), which permits unrestricted use, distribution, and reproduction in any medium, provided the original work is properly cited. 